\title{
The guarantee of freedom of association and collective bargaining rights to domestic workers: two opposite models, Brazil and Canada
}

\author{
A garantia da liberdade sindical e do direito de negociação coletiva dos \\ trabalhadores domésticos: dois modelos opostos, Brasil e Canadá
}

\author{
Ana Virginia Moreira Gomes \\ Rupa Banerjee
}

\section{ABSTRACT}

The study's main objective is to question the exclusion of domestic workers from freedom of association and collective bargaining rights and to propose possible policy solutions to allow the rights to these workers. The paper focuses in the Canadian and in the Brazilian cases. Even though the Brazilian and Canadian models illustrate two very different approaches towards collective organization, both countries present regulatory challenges to the effective recognition of domestic workers' freedom of association and collective bargaining rights. The policy solutions to these challenges in the case of domestic work can serve other groups of vulnerable workers, such as migrants, low wage service workers, informal workers. The methodology is developed through bibliographical and documentary analysis.

Keywords: Freedom of association. Collective bargaining. Domestic work. ILO Convention 189. Brazil. Canada.

\section{RESUMO}

O principal objetivo do estudo é questionar a exclusão dos trabalhadores domésticos dos direitos de liberdade de associação e de negociação coletiva e propor possíveis soluções políticas para permitir esses direitos aos trabalhadores. $\mathrm{O}$ artigo enfoca os casos canadense e brasileiro. Embora os modelos brasileiro e canadense ilustrem duas abordagens muito diferentes para a organização coletiva, ambos os países apresentam desafios regulatórios para o reconhecimento efetivo da liberdade sindical e da negociação coletiva dos trabalhadores domésticos. As soluções políticas para esses desafios, no caso do trabalho doméstico, podem servir a outros grupos de trabalhadores vulneráveis, como migrantes e trabalhadores informais, que são trabalhadores no setor de serviços com baixos salários. A metodologia é desenvolvida por meio da análise bibliográfica e documental.

Palavras-chave: Liberdade sindical. Negociação coletiva. Trabalho doméstico. Convenção 189 da OIT. Brasil. Canadá.

\section{Introduction ${ }^{1}$}

Domestic workers in most countries have no legal protection to exercise their freedom of association and collective bargaining rights (FA/CB). The peculiar characteristics of domestic work do not lend themselves to labour regulations based on the conventional employment relationship within industrial workplaces. Even though domestic workers have been striving to organize collectively for more than a century, lack of legal regulation has hindered these attempts (SHAH; SEVILLE, 2011/2012; MIRANDA, 2007; VAN RAAPHORST, 1988). However, the number of people working in atypical arrangements has steadily risen in recent years

Doctor, Professor, Faculty of Law, Universidade de Fortaleza - UNIFOR, Fortaleza - CE - Brazil. E-mail: avmgomes@gmail.com.

Doctor, Assistant Professor, Ted Rogers School of Business Management, Ryerson University, Toronto - Canada. E-mail: banerjee@ryerson.ca.

This research received a grant from the Centre for Labour Management Relations, Ryerson University. 
(SMIT; FOURIE, 2010; BLACKETT, 2005; SMITH, 2000). Moreover, both in national contexts and in the international order, the rights of freedom of association and collective bargaining have been affirmed as fundamental rights. It is time to update theoretical frameworks to better fit the new reality.

This paper aims to develop a critical analysis of the exclusion of domestic workers from coverage under labour relations legislation in light of recent recognitions of FA/CB rights as fundamental rights and to elaborate on policy solutions for the recognition of these rights. This proposal fills an important gap in our knowledge by analyzing viable regulatory regimes for guaranteeing FA/CB rights to domestic workers. The study focuses in the Canadian and in the Brazilian cases, but will also analyze some examples from other countries that have developed different models for the collective actions of domestic workers.

The Brazilian and Canadian models illustrate two very different approaches towards collective organization. The Brazilian system is characterized as a corporatist model that on one hand guarantees strong protection and legal interference concerning trade union creation, and on the other does not promote real representativeness. The Canadian system follows the Wagner Act model: on one hand promoting the self-organization of workers in the workplace through procedural rules; and on the other, based on the representativeness of the trade union. Each model presents characteristics that can fit or not to the peculiarities of domestic work. Our goal is to explore the compatibilities and incompatibilities of these models with domestic workers' collective organization and draw from this analysis some policy proposals.

The study addresses two research questions: a. does the exclusion of domestic workers from labour relations regulations violate the principle of freedom of association? and $b$. what policies would be effective in guaranteeing FA/CB rights for domestic workers? The first part of the paper will develop a theoretical and legal justification for the recognition of FA/CB rights as domestic workers' fundamental rights. The second part will examine the feasibility of a regulatory regime for guaranteeing FA/CB rights to domestic workers, taking into account the Canadian and the Brazilian models.

Previous studies have examined domestic work through various perspectives: labour conditions, migration, gender, family, race in Canada (ARAT-KOC, 1989; FUDGE, 2011; HODGE, 2006; ANDERSON, 2010; MARINCOLA, 2011) and in Brazil (COSTA, 2007; MELO; CONSIDERA; SABBATO, 2016; TELES, 2014). Some studies, based primarily in the U.S., have focused on freedom of association and collective rights of domestic workers (SMITH 2000, NEW YORK STATE DEPARTMENT OF LABOR 2010, HAYASHI 2010, SHAH AND SEVILLE 2011/2012). FA/CB rights have been reaffirmed as fundamental rights in the international order by the International Labour Organization (ILO) in three separate promulgations: the 1998 Declaration on Fundamental Principles and Rights at Work, the 2008 Declaration on Social Justice for a Fair Globalization and the 2011 Convention 189 on Decent Work for Domestic Workers (BLACKETT, 2012; ILO, 2012; MANTOUVALOU; ALBIN, 2012). In addition, the Supreme Court of Canada (SCC) has expanded the meaning of Section 2(d) of the Charter of Rights and Freedoms to recognize the freedom to engage in collective bargaining as part of the right to freedom of association. In the case of agricultural workers, the SCC ruled that the exclusion of agricultural workers from the Ontario Labour Relations Act violated the Charter, requiring the government to pass a law that would protect their FA/CB rights (Dunmore Case 2001). In Brazil, a constitutional amendment recognized collective bargaining rights to domestic workers in 2013. A 2016 UN Report on freedom of association explains that "The International Covenant on Economic, Social and Cultural Rights requires that States ensure that people can organize and join workers' associations that address their concerns, and that particular attention be given to domestic workers". These national and international developments have altered the context for considering a system to guarantee FA/CB rights to domestic workers. Thus, there is a need to re-visit the issue and to consider anew possible policy solutions.

The methodology is developed through bibliographical and documentary analysis, constituting qualitative study with descriptive, explanatory and exploratory purposes. 


\section{Does the exclusion of domestic workers from labour law regulations violate the principle of freedom of association?}

Domestic work is considered one of the most precarious form of work. Not only domestic workers suffer poor working conditions, receive low wages and are subject to all types of violence and exploitation, they also suffer legal precariousness (MANTOUVALOU; ALBIN, 2012), that is, in many jurisdictions domestic work is still excluded from employment and labour laws. On the issue of how best to reverse this situation of vulnerability, effective solutions are not simply about guaranteeing labour standards (BLACKETT, 2005). Since domestic workers miss two key dimensions of labour law: they are not guaranteed fair employment conditions and have no effective way to express their autonomy (SIMI, 1967), it is essential to guarantee also that these workers are able to express their autonomy. When they have no protection to form and join unions and to bargain collectively (ILO, 2000; ILO, 2004b), they are not perceived as workers who are capable of collective action to express their interests and regulate their own relations. At the end, when domestic workers do not have their FA/CB recognized, all the efforts to guarantee decent work conditions are in vain.

The approval of ILO Convention 189 in 2011 had one important initial effect to the issue of the legal protection of FA/CB to domestic workers: it put the lights on the work done by domestic workers' associations, recognized their role and gave them their own space in forums like the International Labour Conference. According to the ILO, this process "galvanized the domestic workers' movement, fostering its emergence within trade union organizations or bringing it closer to them" (ILO, 2012, III).

The International Domestic Workers Network (IDWN), established in 2007, lead a campaign to the adoption of an international convention on domestic work. The campaign for the adoption of the Convention 189 counted with the participation of IDWN, Women in Informal Employment Globalizing and Organizing (WIEGO), International Trade Union Confederation (ITUC) and national associations through the organization of workshops, publication of reports on the necessity of a convention, and participation of domestic workers organizations ${ }^{2}$ in the ILO 2009, 2010 and 2011 International Conference (WIEGO, 2016). The process of adopting this new convention revealed how essential is the role played by domestic workers' associations in improving the working conditions of these workers. This importance can be seen in concrete actions by trade unions in the national spheres. ${ }^{3}$

The Convention 189 recognizes this importance by guaranteeing to domestic workers their right to freedom of association and collective bargaining, explicitly establishing that Members States should "protect the right of domestic workers and employers of domestic workers to establish and, subject to the rules of the organization concerned, to join organizations, federations and confederations of their own choosing" (Article 3, §3). Even before the explicit recognition by the Convention, the ILO Committee on Freedom of Association had already decided that: "Domestic workers are not excluded from the application of Convention No. 87 and should therefore be governed by the guarantees it affords and have the right to establish and join occupational organizations" (ILO, 2006, §267).

The Committee has decided also that domestic workers' trade unions have the right to access the workplace even if the workplace is a private household, as it is the case of domestic workers (ILO, 2006, §1108). The ILO is very explicit in recognizing the legal right to FA/CB to domestic workers (ILO, 2012, 2) ${ }^{4}$ Therefore, any regulation that exclude or restrict the freedom of association and the right to collective

In addition to these organizations, as Matilla (2011) explains, the adoption of the Convention "was at least partly a result of the intensive lobbying and increasing pressure from organisations such as Migrant Forum Asia, Amnesty International, Anti-Slavery International, and the internationally recognized Indian National Domestic Workers Movement".

In a survey among European trade unions, organizing domestic workers, raising public awareness on their working conditions, collective bargaining, lobbying and legal support were cited as the main activities of a trade union in the field of domestic work (CARLS, 2012).

4 Even though, until the adoption of Convention 189 there has been a long period of silence by the ILO about the legal protection of domestic workers. See Blackett, 1998. 
bargaining of domestic workers violates the principle of freedom of association and the principle of collective bargaining, protected by Conventions 87 and 198, respectively, and recognized by the 1998 ILO Declaration as fundamental rights of all workers.

The United Nations (UN), nonetheless, recognizes that many countries still exclude these workers from the right to bargain collectively and are not recognized freedom of association (UNITED NATIONS, 2016). Domestic workers are being excluded by law or have no ways to effectively exercise these rights. ${ }^{5}$ In both cases, the result is the same: domestic workers are only allowed to associate in women's, migrant's, community's associations. Or when they can form a trade union and have right to collective bargaining, still have no effective way to negotiate (HOBDEN, 2015).

The usual main argument used in excluding or restricting these rights for domestic workers is the fact that they do not fit in the trade union model build by Labor Law based on a standard employment relationship. Domestic workers work isolated in a private home performing a work that still in many countries is not considered to have an economic value. This argument disregards the role of law in promoting domestic workers' rights, more specifically FA/CB rights, since it argues that the peculiarities of domestic work, and not the absence of legal protection, are the factors that substantially interfere with the right to collective bargaining (FARADAY, 2012).

In a larger picture this thinking has two very serious consequences to the regulation of labour. First, it restricts the role of Labour Law only to standard work relationships, excluding from its protection nonstandard employment relationships where most of precarious types of work can be found. Second, it reveals the incapacity of changing the traditional regulatory models in order to include these non-standard employment relationships. In synthesis, the current situation in many countries is that workers who are in so much need of Labour Law protection are exactly the ones excluded from it. In the case of domestic workers, in addition to the peculiarities of the work, it is a type of work done mostly by women, many of whom are migrants, from specific racialized groups, and often with low levels of education (ILO, 2004; EHRENREICH; HOCHSCHILD, 2002; ANDERSON, 2000; CHANG, 2001; FOLBRE; NELSON, 2000; MEAGHER, 1997). The absence of the law becomes one more element reinforcing the precariousness of this type of work. Being an atypical type of work performed by specific groups in society that already are subject of some sort of discrimination and ignored by the law has subjected domestic work to exploitation by employers in developed and developing countries alike. The recognition of their rights of FA/CB would mean to provide domestic workers with an essential instrument (as it has been the case of other workers) to empower these workers in the employment relationship.

When the ILO guarantees the principle of freedom of association through its conventions, recommendations and decisions of the Committee of Freedom of Association, it does not impose any given system as the only one that would comply with the principle. The specific rules of each legal system concerning trade union and collective bargaining should be formulated by each member State according to their practices and customs. Thus, there is no "right" model of freedom of association. This loosen approach is even more true when it concerns domestic workers. Since, most countries still do not or do not fully recognize FA/CB rights to domestic workers, there is still some incertitude on what type of labour relations model would fit the peculiarities of domestic work, and most important, would be effective. If we look at countries that already have some rules in place, they differ a lot from each other. Considering this, we will next examine two different labour relations models, analyze how they comply with Convention 189 concerning freedom of association and what policies would be need to include domestic workers in their protection. 


\section{The brazilian case}

Brazil is an important case for the study of regulation of domestic work. Being one of the biggest employers of domestic workers among developing countries with 6.2 millions domestic workers (IBGE, 2016), until 25 years ago, domestic workers had almost no labour rights. In this period of time, the country developed one of the most advanced labour rights law for domestic work among ILO members. In 1988, the new Federal Constitution guaranteed to domestic workers some of the fundamental labour rights guaranteed to all employees. ${ }^{6}$ In 2006, law \#11.324 changed law \#5.859 that regulated domestic work since 1972, expanding labour rights guaranteed to these workers. Law n.11.324 recognized the right to thirty days of paid vacation, employment protection for pregnant workers, paid legal holidays, and the prohibition of wage discount in case of supply of meals, housing and hygienic products by the employer (BRASIL. MTE, 2007, at 6). In 2008, decree \#6481 included domestic child labour among the worst forms of child labour and prohibited domestic work for workers under the age of eighteen years old. This decree creates the Brazilian list of worst forms of child labour in accordance with ILO Convention 182 ratified by Brazil.

In 2013, Constitutional Amendment 72/2013 was approved, recognizing to domestic workers all fundamental labour rights guaranteed to a typical employee, such as indemnization in case of dismissal without cause, unemployment insurance, extra pay for night-shift work, family bonus, overtime pay, limited hours of work, severance pay indemnity fund system (FGTS), and occupational accident insurance. In 2015, Law \#150 regulated the exercise of the new recognized rights, regulating the domestic work contract as well asthe payment of social security and tax contributions (COSTA; GOMES, 2016).

In Brazil, informality has decreased among domestic workers. Between 2001 and 2009, the number of formal domestic workers has increased $30 \%$ while the number of informal domestic workers increased $20 \%$ (IPEA, 2011). Formalization has continued to increase during the first decade of the 2000s (IPEA, 2011); however, formal domestic workers still are only $33.2 \%$ of all domestic workers in 2016 , while $77.3 \%$ of workers are formal in the private sector (IBGE, 2016).

Looking at a brief profile of domestic workers in Brazil gives us the social and economic significance of having this parcel of workers excluded from the formal market. Domestic work is one of the biggest professional categories in Brazil (10\% of the labour force in the second trimester of 2016) (IBGE, 2016), the second most common job for women ( $92 \%$ of domestic workers are women), and one of the main jobs for African-Brazilians (62\% of domestic workers are African-Brazilians) (IBGE, 2016). In 2009, most of them had elementary school level (41.9\%) (IBGE, 2010). To effectively guarantee labour rights and social security rights to these workers means to reach the poorest groups in society.

In Brazil, domestic workers have guaranteed by the Federal Constitution FA/CB rights. Article $7^{\circ}$, sole paragraph, of the Constitution states as a fundamental right of domestic workers the recognition of their collective agreements. As a result, domestic workers are included in the country's corporatist labour relations system. ${ }^{7}$ In 2016, there were 25 domestic workers' trade unions and 3 employers' trade unions registered at the Ministry of Labour in Brazil. The first domestic workers' trade union was created in 1936 in the province of São Paulo - the Santos Professional Association of Domestic Workers. At that time, their two main objectives were to be recognized by the State as a trade union and the inclusion of domestic workers in the protection of Labour Law (COSTA, 2007). Only, in 1972, one of these goals was achieved. The president of the Santos Professional Association of Domestic Workers had a meeting with the ministry

Article 7 of the 1988 Constitution recognized to domestic workers ten of the twenty nine fundamental labour rights: minimum wage; irreducibility of wage; annual bonus equal to one month's salary; paid weekly rest, preferably on Sundays; annual paid vacation (30 days) with remuneration at least one third higher than the normal wage; 120 days paid maternity leave; five days paid paternity leave; notice of dismissal; as well as of integration in the social security system.

For a more detailed analysis of the main characteristics of the Brazilian labour relations system - the professional category, the unicity and the mandatory trade union dues - and all the problems generated by this system, see Gomes and Prado (2011). 
of labour at the time to present their demands on the inclusion of domestic work in the labour legislation. The answer came with the promulgation of the federal law \#5.859 that recognized a few employment rights to domestic workers. ${ }^{8}$

Domestic workers' trade unions continue to be organized, but not legally registered as trade unions and founding little support from the traditional trade union movement. In 1997, the National Federation of Domestic Workers was created (Federação Nacional das Trabalhadoras Domésticas - Fenatrad). The Fenatrad is also affiliated to the Central Única dos Trabalhadores - CUT. Notwithstanding the affiliation of domestic workers' trade unions to CUT, the trade unions often reported finding more support from the AfroBrazilian and feminist movements than from the traditional trade unions. ${ }^{9}$

Fighting against the lack of legal recognition and little support from other labour groups, domestic workers' trade unions in Brazil were able to have a central role in the movement for the recognition of labour rights and in making public cases of labour rights' violation, sexual harassments and labour accidents. In 1988, with the promulgation of the new Federal Constitution, the domestic workers' trade union organized in order to have guaranteed some fundamental labour rights to domestic workers. After 1988, there was still no consensus in the jurisprudence and in the literature whether the Constitution had recognized freedom of association to domestic workers.

We argue that domestic workers had since the promulgation of the Federal Constitution the right to organize in trade unions for two reasons. First, the Constitution guarantees as a fundamental right the right to associate (Article 5, Line XVII), second there is no explicit restriction of this right in relation to domestic workers by the Constitution. However, the majority of the literature considered that they could not organize in trade unions as they did not constitute a professional category and their employers did not constitute an economic category (RODRIGUES, 2009). Notwithstanding this understanding, the Ministry of Labour in Brazil gradually started to accept the registration of Brazilian domestic workers. The Campinas Domestic Workers' trade union, for example, was officially registered as a trade union in 2008 (BRASIL. MTE, 2008).

Being registered as a trade union, however, did not give them the prerogative to negotiate, since the Federal Constitution did not guarantee the right to collective bargaining to domestic workers. A decision of the Superior Labour Court confirmed this restriction on domestic workers' rights: "The Constitution does not recognize collective agreements of domestic workers (Article 7, line XXVI), therefore there is a logical obstacle to recognize the right of collective bargaining for these workers".

Only in 2013, the demand of domestic workers' trade unions for an equalization of labour rights between domestic workers and employees entered a new phase after the approval of the Constitutional Amendment 72. The constitutional amendment recognizes to domestic workers the fundamental right to collective bargaining. This guarantee opened a whole new world of possibilities. There was no legal doubt on their right to register their trade unions, nor on their right to collective bargaining.

An immediate consequence of the constitutional change was an increase in the number of registered trade unions and applications for registration. In the context of the Brazilian corporatist system, however, this increase does not entirely reflect an effective organization of domestic workers. It is hard to tell how many of the new trade unions are representative or are only a result of an opportunist action from some group intending to hold the legal representation of domestic workers in a certain municipality. The same is valid for domestic workers' employers' trade unions. As in Brazil, employer associations are also considered trade unions and have the same legal treatment as workers' trade unions, with the constitutional change, domestic workers' employers' trade unions will also experience an increase in number. In synthesis, on one side, the corporatist system facilitates the creation of domestic workers' and their employers' trade

\footnotetext{
Another important action of the Santos trade union was a campaign against live-in domestic workers. The campaign sought to allow domestic workers to live in their own homes, what they argued would be essential to emancipate domestic workers, denying the idea that domestic workers are a part of the employers' families (COSTA, 2007).

9 For example, during the negotiation for the adoption of the1988 Federal Constitution, domestic workers trade unions found in these movements, the support that was lacking from traditional trade unions (COSTA, 2007).
} 
unions; on the other side, the lack of representativeness characterizes the corporatist trade union in other categories, might also be a problem among domestic workers.

One important indicator of the real organization of domestic workers will be the negotiation of collective agreements. On this topic, since the constitutional amendment, already one collective agreement was negotiated. In 2013, a collective agreement between the Sindicato das Empregadas e Trabalhadores Domésticos da Grande São Paulo (SINDOMÉSTICA) and the Sindicato dos Empregadores Domésticos do Estado de São Paulo (SEDESP). The agreement deals with wages, payment of wages, vacation, hours of work, night shift, travels, room and board, transportation, dismissal, unemployment insurance, maternity stability and trade union dues. Mostly the agreement reaffirms what is already established in the Labour Code (CLT) and in the Constitution, adding new conditions specially, on minimum wage and compensation of hours. Since 2013, the trade unions already negotiated three more agreements in 2014, 2015 and 2016.

The corporatist rules have repercussions not only on trade union creation, but also on the development of collective bargaining. According to the law, as the trade unions are registered, they can negotiate. When they reach an agreement, this agreement is valid to the entire professional and economic category that is, all workers are covered by this agreement and all employers are obliged to it. It is not relevant the affiliation to the trade union, nor any type of involvement in the organization of the category. Achieved the agreement, workers can complain to the labour courts in case of violation of its clauses. As the registration of a trade union in Brazil follows the first-come, first-serve rule, there is a risk of a non-representative trade union negotiates an agreement. This problematic situation is not peculiar to domestic workers. It is common to all workers in Brazil.

However, in the case of the typical employee this excessive interference of the law might generate more dysfunctional consequences than in the case of domestic workers. As the typical employee works in a traditional workplace and not isolated from other workers, he/she does not face the same obstacles to unionization as domestic workers. In other words, the typical employee is capable and had the right to fully exercise its freedom to establish "the organisations of their own choosing" (ILO, Convention 87, Article 2). The law should protect the exercise of this freedom, promoting representativeness and preventing unfair labour practices.

In the case of domestic workers, they work in a private household and isolated from other workers. These two conditions by themselves already pose strong obstacles to their unionization and collective bargain. The fact that they work in a private household make it harder the access of a trade union to the domestic worker. Since they work isolated from each other, it is hard to domestic workers to organize a reunion. The isolation of domestic workers also compromises an important feature of collective action. Among other achievements, the organization in a trade union in a certain degree depersonalizes worker's voice and action. This feature makes it possible for workers to expose and try to resolve workplace's conflicts without being individually exposed to a retaliatory measure from the employer. For domestic workers, it will always be personal. The decision to organize a trade union, to affiliate to a trade union, any complain made through a trade union. In consequence of all this, it is much harder for domestic workers to organizing a trade union than to a typical worker.

The Brazilian corporatist system imposes a model of organization based on the unionization by categories, the legal exclusivity of representation of the category and mandatory trade union's dues. All this, at the cost of the low representativeness of trade unions, since membership involvement in the creation of the trade union is not necessary. For typical employees, these rules mean a strong restriction in their individual freedom to create the organizations according to their convenience. For domestic workers, these rules might mean a necessary protection that will allow them to organize in trade unions. The organization in categories, the creation of a trade union without membership requirements or a vote, the exclusivity of representation for the whole category provide to domestic workers an easier way to organize. The cost of low representativeness is still there, but a strong membership might not be an essential feature of this stage of domestic workers' association. 


\section{The canadian case}

Like most jurisdictions, Canada does little to protect domestic workers' rights to freedom of association. Although domestic workers are entitled to the same employment standards rights as other workers, these rights are poorly enforced. Since the majority of formal domestic workers in Canada are migrants who came to the country through the Live-in Caregiver Program (LCP), they are particularly vulnerable due to some of the legislated requirements of this program (SPITZER; TORRES, 2008). First, LCP workers had to live in their employer's household and could not have any other type of job or work for another employer than the one authorized in the work permit (FARADAY, 2012). Since 2014, due to changes in the legislation, domestic workers are able to opt to live out. Second and most important, after working for two years (or 3,900 hours) as a full time domestic worker within a period of four years from the time of arrival, the worker can apply for a permanent residence visa. The combination of these peculiarities can make a worker reticent in reporting abuses by the employer (FUDGE, 2011; MARINCOLA, 2011; HODGE, 2006). The worker may fear that filing a complaint against the employer could lead to termination and, as a result, prevent the worker from acquiring permanent resident status. ${ }^{10}$

Under these circumstances, the domestic worker may accept working in conditions not specified in the contract, e.g., longer working hours, fewer or no rest, and performing tasks that are not part of their duties in the original contract (OXMAN-MARTINEZ; HANLEY; CHEUNG, 2004). As there is no effective labour inspection, domestic workers facing a violation of their rights can only file a claim to the Minister of Labour or go to the courts. Informal domestic workers (full- or part-time) are often even more vulnerable, since they have no written contract and no social protection.

Domestic workers have almost no union representation (ARAT-KOC, 1989) and cannot get any help in reporting abuse. They have no legal protection to exercise their freedom of association and collective bargaining rights, being excluded from labour relations regulations in most provinces - for example, the Ontario Labour Relations Act - OLRA (Section 3. "This Act does not apply, (a) to a domestic employed in a private home").

Canada has not yet ratified ILO Conventions 87 and 189, but has already been the subject of a complaint before the ILO's Committee of Freedom of Association for denying domestic workers' freedom of association rights by excluding them from protection under Section $3 a$ of the OLRA. The Canadian government has stated that certain categories of workers are legitimately excluded from the Act, because the statutory regime is not appropriate for non-industrial workplaces. The ILO has asked for creativity in finding new legal solutions to guarantee freedom of association to domestic workers (ILO, 2010).

Taking the case of Ontario, the OLRA system is based on the organization of a bargain unit by a trade union freely constituted. The system also has its version of exclusivity of representation in the bargaining unit, but different from the Brazilian corporatist system, the exclusivity is achieved by a certification vote among the workers in that bargaining unit. Before the certification vote, the trade union must according to the OLRA proves that " 40 percent or more of the individuals in the bargaining unit proposed" by the union "appear to be members of the union at the time the application was filed" through signed membership cards (OLRA, Section 8(2)). Only after the trade union complies with this rule, the Labour Board authorizes a certification vote. In the certification vote, the trade union must receive more than $50 \%$ of the votes. On one hand, this system confers much more representativeness to the certified trade union than the first-come, first-serve Brazilian rule concerning the unicity. We are not ignoring the hardship that trade unions face to organize a workplace and even to get to the point of having a certification vote, but just emphasizing that the workers' participation in the certification of the trade union is a way to ensure the representativeness of that trade union. On the other, the OLRA poses three main obstacles to the unionization of domestic workers:

10 Even though they can change employers, there is still the fear that this interruption might hurt the permanent resident visa application. 
the concept of an appropriate bargaining unit, the need to provide membership support and go through a certification vote and the lack of employers' associations.

An appropriate bargaining unit should cover more than one worker, avoid the fragmentation of the representation and provide that workers share a community of interest. ${ }^{11}$ Domestic work is performed in a fragmented way. As we have said before, domestic workers work isolated from each other for different employers. Unless we accept a bargaining unit of one employee, which does not make sense in terms of collective organization, there is a need to make this fragmentation compatible with the idea a bargaining unit. One suggestion would be to include in the possibilities for a bargaining unit for domestic workers a geographical dimension and to disregard the multiplicity of employers. In this way, it would be possible to have a bargaining unit of private households in a city or province.

The need to provide membership support and go through a certification vote adds another challenge to domestic workers' trade unions due to the fact that these workers work each of them to different employers in a private household. If for a traditional trade union, it is hard to access information on the workforce of a factory, it is much harder for a domestic workers' trade union to find the domestic workers and to establish contact with them. The linkage between domestic work and migrant work in Canada gives a specific feature to this problem. On one hand, the fact that in Canada the majority of formal domestic workers are migrant workers on the LCP might facilitate the access of trade unions to domestic workers through migrant workers' associations, such as the Filipino Migrant Workers Movement. ${ }^{12}$ On the other hand, most of these workers do not have domestic work as their career. They are professionals, who had a career back home and are in the domestic work in a temporary basis, aiming to become a permanent resident in Canada. Even in those cases, where the worker is not able to transition to another type of work after becoming a resident, the worker might not identify himself/herself as a domestic worker in a way to decide to organize or join a domestic workers trade union. Thus, there are structural and ideological obstacles to gather the necessary support to be certified as the exclusive trade union for the workers in a certain bargaining unity.

For a brief period (from 1993 to 1995) domestic workers were included in the OLRA. Fudge (1997) has analyzed the political and ideological motivations of this. The author concludes that the mere formal inclusion of domestic workers in labour law regulations not adapted to this type of work renders it ineffective. Borowy and Fudge (1993) raise a number of possibilities on how the Ontario Labour Relations Act could be changed to accommodate the rights of domestic workers. The authors argue that the labour relations model would have to move to a broader bargaining unit and emphasize the need for a central registry of domestic workers.

In addition to that, since it makes no sense to have collective bargaining with individual employers, in the case of domestic workers, it is necessary to have domestic workers' employers' associations in order to participate in collective bargaining. There are still no such associations. However, if we look at the example of other countries where domestic workers are involved in collective bargaining, we will find interesting alternatives to solve this problem. In Uruguay, since 2008 the Liga de Amas de Casa, Consumidores y Usuarios de la República Oriental del Uruguay has been representing domestic workers' employers by invitation of the Ministry of Labour and participating in tripartite wage councils (GOLDSMITH, 2013, p. 9). ${ }^{13}$

Finally, we should consider the question posed by Langille (2009), but also addressed by Blackett and Sheppard (2003): "is there a rational reason why certain people are excluded from the statutory regime that instantiates a fundamental freedom open to others?" Following the ILO's advice, this paper suggests that the Supreme Court of Canada (SCC)'s decision that expanded the meaning of Section 2(d) of the

According to the OLRA Section 1(1), a bargaining unit is "a unit of employees appropriate for collective bargaining, whether it is an employer unit or a plant unit or a subdivision of either of them".

A similar experience happens in Switzerland, where many domestic workers are migrant workers. See Alleva and Moretto (2011).

13 See also the experience of collective bargaining models for domestic workers in France, Germany, Switzerland and Uruguay (ALLEVA; MORETTO, 2011; ILO, 2011). 
Charter of Rights and Freedoms ${ }^{14}$ to recognize the freedom to engage in collective bargaining as part of the right to freedom of association (BOGG; EWING, 2012) may reverberate to the case of domestic workers. In Dunmore case, 2001, the SCC ruled that the exclusion of agricultural workers from the Ontario Labour Relations Act violated the Charter, requiring the government to pass a law that would protect their FA/CB rights. This study suggests that the exclusion of domestic workers from Canadian standard labour relations laws violates the Section 2(d) of the Charter of Rights and Freedoms. Considering the Dunmore decision, we argue that the case of domestic workers and agricultural workers are similar such that it is reasonable to argue that domestic workers' FA/CB fundamental rights are also being violated. The SCC found that the exclusion of agricultural workers from the protection of the OLRA violated Section 2(d) of the Charter (Dunmore v. Ontario 2001). Dunmore was the first of the three cases (the other two are: Health Services and Support - Facilities Subsector Bargaining Association v. B.C.2007 and Ontario v. Fraser 2011) that have redefined the meaning of section 2 (d) of the Charter, including the right to collective bargaining under the right to freedom of association.

In Dunmore, the SCC ruled that Section 2(d) of the Charter includes, among other collective activities, the freedom of workers to make collective representations to their employers. In excluding agricultural workers from the legal protection granted to all other workers in the Ontario Labour Relations Act, the Ontario government prevented these workers from exercising this freedom, and hence, violated the Charter. In B.C. Health Services, the SCC ruled that the Section 2(d) of the Charter includes a right to collective bargaining. In that case, the SCC decided that a British Colombia law that restricted collective bargaining and collective agreements of health workers violated their collective bargaining right and, therefore, Section 2(d) of the Charter (ETHERINGTON, 2009). Ontario. In Fraser the SCC addressed the compatibility of the Ontario Agricultural Employees Protection Act 2002 (AEPA) with the collective bargaining right protected by Section 2(d) of the Charter. Even though the AEPA did not impose a duty to bargain in good faith, the SCC ruled that it was consistent with Section 2(d), based on the argument that it was not clear that the APEA would prevent agricultural workers from exercising their right to collective bargaining.

Considering the reasoning developed by the SCC in these three decisions and court of appeals' decision on the matter, this paper suggest that domestic workers' exclusion violates Section 2(d) of the Charter since the exclusion of domestic workers from the protection of the Ontario Labour Relations Act substantially interferes, as the SCC ruling stated on Dunmore 2011, with the right of domestic workers to collective bargaining.

The exclusion of domestic workers by the Ontario Labour Relations Act is a disproportional measure in accordance with Section 1 of the Charter. Following a two-step proportionality test, the exclusion does not seem to be justified by a "pressing and substantial concern". Among the possible concerns, the common argument that the Wagner Act model used by the OLRA does not fit the peculiarities of domestic work cannot be considered a "pressing and substantial concern", but a technical regulatory difficulty. The exclusion of domestic worker does not constitute an adequate and necessary measure to address this concern. (R. V. OAKS, 1993; ALEXY; RIVERS, 2010). Furthermore, the SCC ruling establishes that the right to collective bargaining is not restricted to any given model of labour relations (B.C. HEALTH SERVICES; BLACKETT, 2009).

\section{Conclusion}

There have been some important legal developments concerning the recognition of FA/CB to domestic workers in the case of Brazil and Canada. These two countries have very different labour relations systems. While Canada's labour relations system is based on the Wagner Act model, Brazil's system is characterized

\footnotetext{
14 Section 2(d) of the Charter of Rights and Freedoms: "2. Everyone has the following fundamental freedoms: ...(d) freedom of association".
} 
by its corporatist structure that legally guarantees to one trade union the representation of a professional category. ${ }^{15}$ On both cases, labour law does not fit entirely in the peculiarities of domestic work and, as a result, domestic workers are excluded from labour law's coverage, as it happens in most provinces in Canada, or face obstacles to have their FA/CB rights enforced, as it is the case in Brazil.

Address the role of law in promoting domestic workers' rights, more specifically FA/CB rights, is essential to oppose the idea that the peculiarities of domestic work, and not the absence of legal protection, are the factors that substantially interfere with the right to collective bargaining (FARADAY, 2012). Moreover, the exclusion of domestic workers from labour law regulations violates the principle of freedom of association.

For policy purposes, the case of domestic work unites many characteristics that can serve other groups of vulnerable workers, such as migrants, low wage service workers, informal workers. As the ILO points out, workers in the informal economy are the ones who experience the greatest decent work deficits, including lack of representation and voice at work and lack of participation in channels of social dialogue (D'SOUZA, 2010; ILO, 2002). The fight against the vulnerability and precariousness of atypical workers' demands creative solutions concerning their collective organization and bargaining. The case of domestic workers leads the way in showing what these solutions might be.

\section{References}

ALBIN, Einat; MANTOUVALOU, Virginia. Labor organizing and the law: Active industrial citizenship of domestic workers: Lessons learned from unionizing attempts in Israel and the United Kingdom. 17 Theoretical Inquiries in Law, 321, Jan. 2016. 10485 words. Lexis Nexis Academic. Web. Available at: < http://www.lexisnexis.com/hottopics/Inacademic/?_session=51bc2cb2-a897-11db-b6610008a0c59 ac.1 1.583747.0.0.0\&_state $=\& w c h p=d G L b V t z-z S k S A \& \_m d 5=e c d d 4 a 8 f 5300 f 363 f d 1926 c 413627 \mathrm{ca} 4>$. Access in: 13 Oct. 2016.

ALEXY, R.; RIVERS, J. A theory of constitutional rights. Oxford: Oxford University Press, 2010. ALLEVA, Vania; MORETTO, Mauro. Domestic workers in Switzerland protected by the country's first sectoral employment contract. Global Labour Columm, 2011. Available at: < http://column.globallabour-university.org/2011/01/domestic-workers-inswitzerland. html>. Access in: 6 Apr. 2017.

ANDERSON, B. Mobilizing migrants, making citizens: migrant domestic workers as political agents. Ethnic and Racial Studies, London, v. 33, n. 1, p. 60-74, 2010.

ANDERSON, B. Doing the Dirty Work? The Global Politics of Domestic Labour. London: Zed Books, 2000.

ARAT-KOC, Sedef. In the privacy of our own home: Foreign domestic workers as solution to the crisis in the domestic sphere in Canada. Studies in Political Economy, Alberta, v. 28, n. 1, p. 33-58, 1989.

BLACKETT, A. The Historic New ILO Decent Work for Domestic Workers Convention and Recommendation. American Journal of International Law, Washington, v. 106, n. 4, p. 778-794, 2012.

BLACKETT, A. Mutual Promise: International Labour Law and B.C. Health Services. Supreme Court Law Review, Ottawa, v. 48, p. 365-407, 2009.

BLACKETT, A. Promoting domestic workers' human dignity through specific regulation. In: FAUVECHAMOUX, A. (Ed.). Domestic work as a factor of european identity: understanding the globalization of domestic work, 16th-21st Centuries. Bern: Peter Lang SA, 2005. p. 211-237.

BLACKETT, A.; SHEPPARD, C. Collective bargaining and equality: Making connections. International Labour Review, Geneva, v. 142, n. 4, p. 419-457, 2003.

15 For a more detailed analysis, see Gomes and Prado (2011). 
BLACKETT, A. Making domestic work visible: the case for specific regulation. Geneva: ILO, 1998. BOGG, Alan; EWING, Keith. A (Muted) Voice at work? Collective bargaining in the Supreme Court of Canada. Comp. Lab. L. \& Pol'y J., Illinois, v. 33, n. 379, p. 379-416, Spring, 2012.

BOROWY, Jan; FUDGE, Judy. Meeting the needs of vulnerable workers: proposals for improved employment legislation and access to collective bargaining for domestic workers and industrial homeworkers. Toronto: Toronto Organization for Domestic Workers' Rights, 1993.

BRASIL. Ministério do Trabalho e Emprego. Trabalho doméstico: direitos e deveres: orientações. Brasília: MTE, 2007.

BRASIL. Ministério do Trabalho e Emprego. Extrato do Cadastro. 2008. Available at: <http://www3.mte. gov.br/sistemas/cnes/usogeral/HistoricoEntidadeDetalhes.asp?NRCNPJ=5 4.152.285/0001-05>. Access in: 25 Oct. 2016.

CARLS, Kristin. Decent work for domestic workers. The state of labour rights, social protection and trade union initiatives in Europe. 2012. Available at: <http://www.ilo.org/wcmsp5/groups/public/--ed_dialogue/---actrav/documents/publication/wcms_218133.pdf>. Access in: 25 Oct. 2016.

CHANG, G. Disposable domestics: immigrant domestic workers in the global economy. Cambridge, Massachusetts: Cambridge South End Press, 2001.

COSTA, J. B. Sindicatos das Trabalhadoras Domésticas no Brasil: teorias da descolonização e saberes subalternos. 2007. 286 f. Tese (Doutorado em Sociologia) - Departamento de Sociologia, Brasília: UNB, 2007.

COSTA, K. R.; GOMES, A. V. M. A fiscalização do trabalho doméstico: um possível conflito entre a inviolabilidade do domicílio do empregador e a proteção do trabalho. Revista de Direito do Trabalho, São Paulo, v. 168, p. 123-144, 2016.

D'SOUZA, A. Moving toward Decent work for Domestic workers: an overview of the ILO's work. Geneva: International Labour Organization, 2010.

EHRENREICH, B.; HOCHSCHILD, A. Global woman: nannies, maids and sex workers in the new economy. London: Granta London, 2002.

FARADAY, Fay. Made in Canada: how the law constructs migrant workers' insecurity, September 2012, Metcalf Foundation. Available at:<metcalffoundation.com/wp.../09/Made-in-Canada-Full-Report.pdf>. Access in: 6 Apr. 2017.

FOLBRE, N.; NELSON, J. For love or money - or Both?. Journal of Economic Perspectives, Washington DC, v. 14, n. 4, p. 123-140, 2000.

FUDGE, Judy. Global care chains, employment agencies, and the conundrum of jurisdiction: Decent work for domestic workers in Canada. Canadian Journal of Women and the Law, Toronto, v. 23, n. 1, p. 235264, 2011.

FUDGE, Judy. Little victories and big defeats: the rise and fall of collective bargaining rights for domestic workers in Ontario. In: BAKAN, Abigail B.; STASIULIS, Daiva (ed.). Not one of the family: foreign domestic workers in Canada. Toronto: University of Toronto Press, 1997. p. 119-146.

GOLDSMITH, Mary R. Collective bargaining and domestic workers in Uruguay. Women in the Informal Economy: Globalizing and Organizing and supported by the Solidarity Centre, 2013. Available at: <http://wiego.org/sites/wiego.org/files/resources/files/Goldsmith-Collective-Bargaining-Uruguay-ISBN. pdf>. Access in: 24 Jan. 2017.

GOMES, A.V.M.; PRADO, M. M. Flawed freedom of association in Brazil: How unions can become an obstacle to meaningful reforms in the Labour Law System. Comparative Labor Law \& Policy Journal, Illinois, v. 32, n. 4, p. 843-889, 2011. 
HAYASHI, Reyna Ramolete. Empowering domestic workers through law and organizing initiatives. Seattle J. Soc. Just., Seattle, v. 9, Issue 1, 487, p. 486-535, Fall / Winter, 2010.

HOBDEN, Claire. Domestic workers organize - but can they bargain? Mapping collective bargaining and other forms of negotiation in the domestic work sector, 2015. Available at: <http://www.ilo.org/ wcmsp5/groups/public/---ed_protect/---protrav/---travail/documents/publication/wcms_345704.pdf>. Access in: 25 Oct. 2016.

HODGE, Jarrah. Unskilled Labour: Canada's Live-in Caregiver Program, Undercurrent, Peterborough, v. III, n. 2, p. 60-66, 2006.

INTERNATIONAL LABOUR ORGANIZATION (ILO). Achieving decent work for domestic workers: an organizer's manual to promote ILO Convention No. 189 and build domestic workers' power. Geneva: International Labour Office, ILO, 2012.

INTERNATIONAL LABOUR ORGANIZATION (ILO). Decent work for domestic workers. International Labour Conference, 99th Session, Report IV(2A), 2011. Available at: < http://www.ilo.org/ilc/ ILCSessions/100thSession/reports/reports-submitted/WCMS_151864/lang--en/index.htm>. Access in: 26 Oct. 2017.

INTERNATIONAL LABOUR ORGANIZATION (ILO). Decent work for domestic workers. International Labour Conference, 99th Session, 2010, Report IV(1). Available at: <http://www.ilo.org/ilc/ ILCSessions/99thSession/reports/WCMS_104700/lang--en/index.htm>. Access in: 26 Oct. 2017.

INTERNATIONAL LABOUR ORGANIZATION (ILO). Equality at work: Tackling the challenges (Global report under the follow-up to the Declaration). Geneva: ILO, 2007.

INTERNATIONAL LABOUR ORGANIZATION (ILO). Committee on Freedom of Association Digest Freedom of Association. 5. ed. Geneva: ILO, 2006. Available at: <http://www.ilo.org/wcmsp5/groups/ public/---ednorm/---normes/documents/publication/wcms090632.pdf>. Access in: 24 Jan. 2017.

INTERNATIONAL LABOUR ORGANIZATION (ILO). Towards a fair deal for migrant workers in the global economy. Geneva: ILO, 2004. (Report VI, ILC). Available at: <http://www.ilo.org/public/english/ standards/relm/ilc/ilc92/pdf/rep-vi.pdf>. Access in: 26 Oct. 2017.

INTERNATIONAL LABOUR ORGANIZATION (ILO). Organizing for social justice, Global Report under the follow-up the ILO Declaration on Fundamental Principles and Rights at Work. Geneva: ILO, 2004b. Available at: <http://www.ilo.org/global/publications/ilo-bookstore/order-online/books/WCMS_ PUBL_9221130304_EN/lang--en/index.htm>. Access in: 26 Oct. 2017.

INTERNATIONAL LABOUR ORGANIZATION (ILO). Decent work and the informal economy, International Labour Conference, 90th Session, Report IV. Geneva: ILO, 2002. Available at: <http:// www.ilo.org/public/english/standards/relm/ilc/ilc90/pdf/rep-vi.pdf>. Access in: 26 Oct. 2017.

INTERNATIONAL LABOUR ORGANIZATION (ILO). Women and Men in the Informal Economy: a statistical picture. Geneva: ILO, 2002a. Available at: <http://www.wiego.org/sites/default/files/publications/ files/ILO-Women-Men-Informal-2002.pdf>. Access in: 26 Oct. 2017.

INTERNATIONAL LABOUR ORGANIZATION (ILO). Your voice at work (Global Report under Followup to the Declaration, Report 1(B), ILC, 88th Session). Geneva: ILO, 2000. Available at: <http:// digitalcommons.ilr.cornell.edu/cgi/viewcontent.cgi?article=1008\&context=freedom>. Access in: 26 Oct. 2017.

INSTITUTO BRASILEIRO DE GEOGRAFIA E ESTATÍSTICAS (IBGE). Pesquisa Nacional por_ Amostra de Domicilios continua, 2016 2. Trimestre. Rio de Janeiro: IBGE, 2016. Available at: <ftp:// ftp.ibge.gov.br/Trabalho_e_Rendimento/Pesquisa_Nacional_por_Amostra_de_Domicil ios_continua/ Trimestral/Fasciculos_Indicadores_IBGE/pnadc_201602_trimestre_caderno.pdf>. Access in: 25 Oct. 2016. 
INSTITUTO BRASILEIRO DE GEOGRAFIA E ESTATÍSTICAS (IBGE), PNAD, 2011, Síntese dos Indicadores. Available at:<https://biblioteca.ibge.gov.br/visualizacao/livros/liv61566.pdf>. Access in: 25 Oct. 2016.

INSTITUTO BRASILEIRO DE GEOGRAFIA E ESTATÍSTICA (IBGE). Pesquisa Mensal de Emprego (PME). Algumas das principais características dos trabalhadores domésticos vis-à-vis a população ocupada. Brasília, fev. 2010. Available at: <https://www.ibge.gov.br/home/estatistica/ indicadores/trabalhoerendimento/pme_nova/princ_carac_trab_dom.pdf>. Access in 24 Jan. 2017.

INSTITUTO DE PESQUISA ECONÔMICA APLICADA. Características da formalização do mercado de trabalho brasileiro entre 2001 e 2009. Comunicados do Ipea 88 at 7, 2011. Available at: <http:// www.ipea.gov.br/portal/index.php?option=comalphacontent\&view=alphacontent\&ltemid=133>. Access in: 25 Oct. 2016.

LANGILLE, Brian. The Freedom of Association Mess: How We Got into It and How We Can Get out of It. McGill Law Journal, Montreal, v. 54, p. 177-212, 2009.

MARINCOLA, David. Domestic service work in canada: the living and working conditions 1940s to present, 2011. Available at: <http://hdl.handle.net/10315/9866>. Access in: 25 Oct. 2016.

MANTOUVALOU, Virginia. Human rights for precarious workers: the legislative precariousness of domestic labour. London: UCL Labour Rights Institute Working Paper Series, 2012. Available at:<www. ucl.ac.uk/laws/lri/papers/VM\%20precarious\%20workers.pdf>. Access in: 6 Apr. 2017.

MANTOUVALOU, Virginia; ALBIN, Einat. The ILO Convention on Domestic Workers: from the shadows to the Light. Industrial Law Journal, London, v. 41, 2012. Available at: <http://ssrn.com/ abstract=1963104>. Access in: 6 Apr. 2017.

MEAGHER, G. Recreating Domestic Service: Institutional Cultures and the Evolution of Paid Household Work. Feminist Economics, Houston, v. 3, n. 2, p. 1-27, 1997.

MELO, Hildete Pereira; CONSIDERA, Claudio Monteiro; SABBATO, Alberto Di. Os afazeres domésticos contam. Economia e Sociedade, [S.I.], v. 16, n. 3, p. 435-454, jan. 2016. ISSN 1982-3533. Available at: <http://periodicos.sbu.unicamp.br/ojs/index.php/ecos/article/view/8642815/10368>. Access in: 13 Oct. 2016.

MIRANDA, Susana P. Exploring themes in the scholarship on twentieth century domestic work in Canada and the United States. Left History, Toronto, v. 12, n. 2, p. 113-129, 2007.

OXMAN-MARTINEZ, Jacqueline; HANLEY, Jill; CHEUNG, Leslie. Another Look at the Live-inCaregivers Program (LCP): An Analysis of an Action Research Survey. Conducted by PINAY, the Quebec Filipino Women's Association with The Centre for Applied Family Studies. Working paper \#24, Montréal, QMC-IM, Sept. 2004.

RODRIGUES, M. CF/88, art. $7^{\circ}$, parágrafo único: trabalhador doméstico. In: VILLATORE, M.; HASSON, R. Direito constitucional do trabalho vinte anos depois: Constituição Federal de 1988. Curitiba: Juruá, 2009. p. 489-498.

SHAH, Hina; SEVILLE, Marci. Domestic Worker Organizing: Building a Contemporary Movement for Dignity and Power. Alb. L. Rev., Albany, v. 75, p. 413-446, 2011 / 2012.

SIMI, Valente. Il favore dell'ordinamento giuridico per i lavoratori. Milano: Dott. A. Giuffrè Editore, 1967.

SMIT, Nicola; FOURIE, Elmarie. Extending protection to atypical workers, including workers in the informal economy, in developing countries. The International Journal of Comparative Labour Law and Industrial Relations, Illinois, v. 26, n.1, p.43-60, 2010.

SMITH, Peggie R. Organizing the unorganizable: private paid household workers and approaches to employee representation. North Carolina Law Review, North Carolina, v. 79, p. 45-110, Dec. 2000.

SPITZER, D. L.; S. TORRES. Gender-based barriers to settlement and integration for live-in caregivers: a review of the literature. Toronto, ON: The Ontario Metropolis Centre, 2008. 
THE UNITED STATES OF AMERICA. New York State Department of Labor. Feasibility of Domestic worker collective bargaining. Nov. 2, 2010. Available at: <https://labor.ny.gov/legal/laws/pdf/domesticworkers/domestic-workers-feasibilitystudy.Pdf>. Access in: 5 Apr. 2017.

UNITED NATIONS (UN). Report of the Special Rapporteur on the rights to freedom of peaceful assembly and of association. Seventy-first session Item 69 (b) of the provisional agenda Promotion and protection of human rights: human rights questions, including alternative approaches for improving the effective enjoyment of human rights and fundamental freedoms. 2016. Available at: <http:// freeassembly.net/wpcontent/uploads/2016/10/A.71.385E.pdf>. Access in: 25 Oct. 2016.

VAN RAAPHORST, Donna L. Union maids not wanted: organizing domestic workers, 1870-1940. New York: Praeger, 1988.

WOMEN IN INFORMAL EMPLOYMENT GLOBALIZING AND ORGANIZING (WIEGO). The Campaign for a Domestic Workers' Convention. 2016. Available at:<http://wiego.org/organizing/campaigndomestic-workers-convention>. Access in: 25 Oct. 2016.

Recebido em: 06/04/2017

Aprovado em: 10/10/2017 